\title{
A Survey of Actual Clinical Practice Concerning Blood Pressure Control among Patients with Hypertension in Kanagawa 2014
}

\author{
Nobuo Hatori, Hiroyuki Sakai, Kazuyoshi Sato, Masayuki Miyajima, \\ Shouhei Yuasa, Shingo Kuboshima, Keiichi Kajiwara, Yoshikuni Hara, \\ Kousuke Minamizawa and Masaaki Miyakawa \\ The Kanagawa Physicians Association, Kanagawa, Japan
}

\begin{abstract}
We performed a cross-sectional survey to investigate actual clinical practice concerning blood-pressure control among patients with hypertension in Kanagawa. The guidelines of the Japanese Society of Hypertension (JSH) for the management of patients with hypertension were revised in 2014. From October 1 to November 30, 2014, questionnaires on the care of patients with hypertension were sent via post to members of the Kanagawa Physicians Association in Kanagawa Prefecture, Japan. -Data on 1,105 patients (mean age: $68.4 \pm 12.3$ years, 537 men and 568 women) were obtained. The overall mean systolic blood pressure (BP) of these patients was $128.7 \pm 12.1 \mathrm{mmHg}$ for home monitoring and $132.9 \pm 12.6$ $\mathrm{mmHg}$ for office monitoring; diastolic BP was $75.7 \pm 9.7$ for home monitoring and $77.0 \pm 9.7 \mathrm{mmHg}$ for office monitoring. According to the JSH 2014 guidelines, the target BP was achieved by $68.1 \%$ of all subjects; $89.2 \%$ of late-phase elderly patients (75 years or older); $69.1 \%$ of young, middle-aged, and earlyphase elderly patients (younger than 75 years except in patients with diabetes mellitus [DM] or chronic kidney disease [CKD] with proteinuria); $9.3 \%$ of patients with DM except late-phase elderly patients; and $11.9 \%$ of CKD patients with proteinuria except DM. Cross-sectional analysis showed that the factors significantly associated with an increased likelihood of achieving the target BP were as follows: 1) good medication compliance even for a small number of antihypertensive agents at small amount of doses in patients 75 years and older; 2) good medication compliance in patients in younger than 75 years; 3 ) an older age, a larger proportion in the female-to-male ratio and a lower body mass index in patients with DM except late-phase elderly patients; and 4) usage of a large number of antihypertensive agents in CKD patients with proteinuria. Further follow-up surveys are necessary to investigate changes in clinical practice following the introduction of the revised guidelines.
\end{abstract}

(J Nippon Med Sch 2016; 83: 188-195)

Key words: blood pressure, physicians, guidelines

\section{Introduction}

Elevated blood pressure (BP) is considered a common risk factor for stroke and cardiovascular disease ${ }^{1,2}$, and it is recognized that the normalization of blood pressure is the most important factor in reducing morbidity and mortality ${ }^{3,4}$. In this context, several hypertension management guidelines have been established for patients with hypertension ${ }^{5-7}$.

The Japanese Society of Hypertension (JSH) first published guidelines for the management of hypertension in 2000 (JSH 2000), with revisions in $2004^{9}$ and $2009^{10}$. We investigated clinical practice concerning BP control in patients with hypertension according to the JSH 2009 guidelines in Kanagawa Prefecture on 2008, 2009, and $2011^{11,12}$. These studies showed that, in the management of patients with hypertension, the target BP was achieved in $53.9 \%$ of patients in $2008,55.1 \%$ in 2009 , and $57.1 \%$ in 2011. The JSH revised its hypertension guidelines in April 2014. Thus, the aim of the present study was to investigate clinical practice in Kanagawa Prefecture as it concerned BP control in patients with hypertension according to the JSH 2014 guidelines.

Correspondence to Nobuo Hatori, MD, Kobayashi Hospital, 1-14-18 Sakaecho, Odawara, Kanagawa 250-0011, Japan

E-mail: hatnobu@pa2.so-net.ne.jp

Journal Website (http://www.nms.ac.jp/jnms/) 


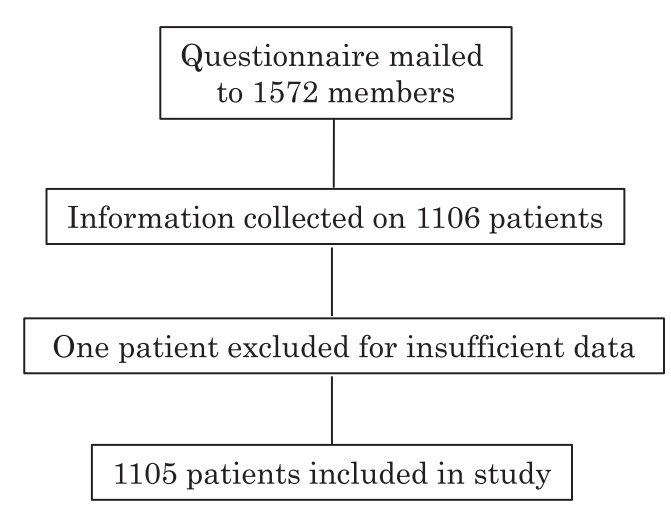

Fig. 1 Patient registration and flow chart

\section{Patients and Methods}

\section{Data and Subjects}

The present study was performed in Kanagawa Prefecture, Japan, from October 1 to November 30, 2014. The survey was based on our previous studies, which have been described in detail ${ }^{11,12}$. A questionnaire was mailed to 1,572 members of the Kanagawa Physicians Association. The questionnaire contained questions on patients' age, sex, body-mass index, concomitant disorders (diabetes mellitus [DM], coronary artery diseases [CAD], stroke, and chronic kidney disease [CKD]), alcohol consumption, current smoking habits, office-measured systolic and diastolic BPs, home BP monitoring, types of antihypertensive agents and their doses, who measured the office BP and what kind of equipment was used, who judged the BP levels, and how effective the medication compliance was. To avoid selection bias, patients were selected as follows: if the final number of the patient's identification number or telephone number matched the final number of the patient's consultation date, he or she was enrolled in the study. To enable dose analysis, the doses of all antihypertensive drugs were adjusted to standard doses that were in accordance with Japanese clinical practice. For example, the standard dose of valsartan is $80 \mathrm{mg}$, which was counted as 1.0 point $^{12}$.

\section{Data Analysis}

We divided patients into four groups according to the JSH 2014 guidelines: 1) late-phase elderly patients (75 years or older) including patients with DM and CKD with or without proteinuria; 2) young, middle-aged, and early-phase elderly patients (younger than 75 years) without DM and CKD with proteinuria, including patients with CAD and CKD without proteinuria; 3) patients with DM who were not late-phase elderly; and 4) CKD patients with proteinuria but not DM who were not late-phase elderly. Within these groups, we analyzed which patient BP targets, according to the JSH 2014 guidelines, were and were not achieved. If there was a difference in achievement in target BP levels between office and home BP measurements, the achievement of the target BP level at home was preferred. In cases where home BP data were absent, they were determined by office BP (46 cases).

\section{Statistical Analysis}

All data were entered into a computer and analyzed with the IBM SPSS Statistics 22.0 software program (IBM Inc., Armonk, NY, USA). Means and standard deviations were calculated for continuous variables and proportions were calculated for categorical variables. The chi-square test was used for comparisons between categorical variables. The Student's $t$-test was used for comparisons with continuous variables. For comparing the total number of antihypertensive drugs and scores, a non-parametric method such as the Mann-Whitney test was employed since the data were not met in the normal distribution. A $p$ value of less than 0.05 was considered significant.

\section{Results}

Data were collected on 1,106 patients. One patient was excluded owing to insufficient patient characteristics (Fig. 1). Thus, the study population consisted of 1,105 patients (537 men and 568 women) (Table 1). The mean patient age was $68.7 \pm 12.3$ years. There were 198 patients with DM, 70 with non-diabetic proteinuria, 68 with CAD, and 48 with cerebrovascular disease (CVD). The reasons for home BP monitoring were as follows: recommended by physicians, $83.4 \%$; patients voluntarily monitored, $8.1 \%$; and noncontrolled office $\mathrm{BP}, 4.8 \%$. Office BPs were mostly measured by physicians using manometers (34\%). The average home systolic BP was $128.7 \pm 12.1 \mathrm{mmHg}$ and average home diastolic BP was $75.7 \pm 9.7 \mathrm{mmHg}$. The average office systolic BP was $132.9 \pm 12.6 \mathrm{mmHg}$ and average office diastolic BP was $77.0 \pm 9.7 \mathrm{mmHg}$. The average number of prescribed drugs was $1.99 \pm 0.9$. Angiotensin II receptor blockers (ARB) were the most frequently prescribed $(78.0 \%)$.

Achievement Ratio of Target BP According to JSH

\section{Guidelines}

The rate of $\mathrm{BP}$ in each of the four groups according to the JSH 2014 guidelines are shown in Table 2. The overall rate of controlled BP was $68.1 \%$ (753 out of 1,105$)$. In patients 75 year and older, the rate of controlled BP was $89.2 \%$, which was the highest rate in the groups. The lowest rate was $9.3 \%$ in patients with DM. The rate of BP 
Table 1 Characteristics and results of 1,105 hypertensive patients

\begin{tabular}{|c|c|c|}
\hline Age (years) & \multicolumn{2}{|c|}{$68.4 \pm 12.3$} \\
\hline Sex (male/female) & \multicolumn{2}{|c|}{$537 / 568(48.6 \% / 51.4 \%)$} \\
\hline Body mass index $\left(\mathrm{kg} / \mathrm{m}^{2}\right)$ & \multicolumn{2}{|c|}{$24.5 \pm 5.4$} \\
\hline Current smoker & \multicolumn{2}{|l|}{$186(16.8 \%)$} \\
\hline Current drinker & \multicolumn{2}{|l|}{$329(29.7 \%)$} \\
\hline \multicolumn{3}{|l|}{ Concomitant disease } \\
\hline $\mathrm{DM}$ & \multicolumn{2}{|l|}{198 (17.9\%) } \\
\hline CKD & \multicolumn{2}{|l|}{$152(13.7 \%)$} \\
\hline CKD with proteinuria & \multicolumn{2}{|l|}{$113(10.2 \%)$} \\
\hline Non-DM & \multicolumn{2}{|l|}{$70(6.3 \%)$} \\
\hline $\mathrm{DM}$ & \multicolumn{2}{|l|}{$43(3.8 \%)$} \\
\hline CAD & \multicolumn{2}{|l|}{$68(6.1 \%)$} \\
\hline CVD & \multicolumn{2}{|l|}{$48(4.3 \%)$} \\
\hline \multicolumn{3}{|c|}{$\begin{array}{r}\text { Patients measured BP at home for the following reasons: } \\
\text { recommended } 922(83.4 \%)\end{array}$} \\
\hline noncontrolled BP & \multicolumn{2}{|l|}{$53(4.8 \%)$} \\
\hline voluntarily & \multicolumn{2}{|l|}{$90(8.1 \%)$} \\
\hline unknown & \multicolumn{2}{|l|}{$40(3.6 \%)$} \\
\hline \multicolumn{3}{|l|}{ Office BP measured by } \\
\hline physicians using manometers & \multicolumn{2}{|l|}{$376(34.0 \%)$} \\
\hline physicians using cuff-oscillometric method & \multicolumn{2}{|l|}{$287(25.9 \%)$} \\
\hline nurses & \multicolumn{2}{|l|}{$351(31.7 \%)$} \\
\hline patients (self-monitoring) & $76(6.9 \%)$ & \\
\hline unknown & $15(1.4 \%)$ & \\
\hline Home & & \\
\hline Systolic BP (mmHg) & $128.7 \pm 12.1$ & \\
\hline Diastolic BP (mmHg) & $75.7 \pm 9.7$ & \\
\hline Pulse rate (beats/min) & $67.7 \pm 9.8$ & \\
\hline Office & & \\
\hline Systolic BP (mmHg) & $132.9 \pm 12.6$ & \\
\hline Diastolic BP (mmHg) & $77.0 \pm 9.7$ & \\
\hline Pulse rate (beats/min) & $74.0 \pm 12.6$ & \\
\hline Total number of antihypertensive drugs & $\begin{array}{c}\text { Number (Ratio) } \\
1.99 \pm 0.90\end{array}$ & $\begin{array}{c}\text { Score } \\
1.93 \pm 1.21\end{array}$ \\
\hline Class of drugs & & \\
\hline Ca channel blockers (CCB) & $841(76.1 \%)$ & $1.15 \pm 0.62$ \\
\hline Single ingredient & 593 & \\
\hline Compound drug & & \\
\hline $\mathrm{ARB} / \mathrm{CCB}$ & 234 & \\
\hline Amlodipine/Atorvastatin & 20 & \\
\hline (single and compound) & $(-6)$ & \\
\hline Angiotensin II receptor blockers (ARB) & $868(78.0 \%)$ & $1.00 \pm 0.40$ \\
\hline Single ingredient & 539 & \\
\hline Compound drug & & \\
\hline $\mathrm{ARB} / \mathrm{CCB}$ & 234 & \\
\hline $\mathrm{ARB} /$ diuretics & 95 & \\
\hline Diuretics & $154(13.9 \%)$ & $0.55 \pm 0.32$ \\
\hline Single ingredient & 60 & \\
\hline Compund drug $\quad \mathrm{ARB} /$ diuretics & 95 & \\
\hline (single and compound) & $(-1)$ & \\
\hline Angiotensin-converting enzyme inhibitors & $44(4 \%)$ & $1.15 \pm 0.52$ \\
\hline $\begin{array}{l}\text { Beta-blockers } \\
\text { (including alpha-beta blockers) }\end{array}$ & $\begin{array}{l}115(10.4 \%) \\
(59)\end{array}$ & $0.83 \pm 0.38$ \\
\hline Alpha-blockers & $95(8.6 \%)$ & $0.46 \pm 0.25$ \\
\hline Aldosteron antagonists & $81(7.3 \%)$ & $0.73 \pm 0.29$ \\
\hline Renin inhibitor & $5(0.5 \%)$ & 1 \\
\hline Other vasodilators & $2(0.2 \%)$ & 1 \\
\hline
\end{tabular}

The score of antihypertensive drugs was adjusted to the standard dose. Abbreviations: DM, diabetes mellites; $\mathrm{CKD}$, chronic kidney disease; $\mathrm{CAD}$, coronary arterial disease; $\mathrm{CVD}$, cerebrovascular disease; $\mathrm{BP}$, blood pressure 
Table 2 Achievement ratio of target BP according to JSH 2014 guidelines

\begin{tabular}{|c|c|c|c|c|c|c|}
\hline Category & Number & Office target BP & Achieved & Home target $\mathrm{BP}$ & Achieved & $\begin{array}{l}\text { Overall achiev- } \\
\text { ment ratio }\end{array}$ \\
\hline $\begin{array}{l}\text { Patients } 75 \text { years or } \\
\text { older }\end{array}$ & 388 & $\begin{array}{l}\mathrm{SBP}<150 \mathrm{mmHg} \text { and } \\
\mathrm{DBP}<90 \mathrm{mmHg}\end{array}$ & $355(91.5 \%)$ & $\begin{array}{l}\mathrm{SBP}<145 \mathrm{mmHg} \text { and } \\
\mathrm{DBP}<85 \mathrm{mmHg}\end{array}$ & $324 / 367(88.2 \%)$ & $346(89.2 \%)$ \\
\hline $\begin{array}{l}\text { Patients younger than } \\
75 \text { years }\end{array}$ & 567 & $\begin{array}{l}\mathrm{SBP}<140 \mathrm{mmHg} \text { and } \\
\mathrm{DBP}<90 \mathrm{mmHg}\end{array}$ & $412(72.5 \%)$ & $\begin{array}{l}\mathrm{SBP}<135 \mathrm{mmHg} \text { and } \\
\mathrm{DBP}<85 \mathrm{mmHg}\end{array}$ & $378 / 550(68.2 \%)$ & $392(69.1 \%)$ \\
\hline Patients with DM & 108 & $\begin{array}{l}\mathrm{SBP}<130 \mathrm{mmHg} \text { and } \\
\mathrm{DBP}<80 \mathrm{mmHg}\end{array}$ & $38(35.2 \%)$ & $\begin{array}{l}\mathrm{SBP}<125 \mathrm{mmHg} \text { and } \\
\mathrm{DBP}<75 \mathrm{mmHg}\end{array}$ & $16 / 100(16.0 \%)$ & $10(9.3 \%)$ \\
\hline $\begin{array}{l}\text { Patients with CKD but } \\
\text { non-DM preteinuria }\end{array}$ & 42 & $\begin{array}{l}\mathrm{SBP}<130 \mathrm{mmHg} \text { and } \\
\mathrm{DBP}<80 \mathrm{mmHg}\end{array}$ & $9(21.4 \%)$ & $\begin{array}{l}\mathrm{SBP}<125 \mathrm{mmHg} \text { and } \\
\mathrm{DBP}<75 \mathrm{mmHg}\end{array}$ & $4(9.5 \%)$ & $5(11.9 \%)$ \\
\hline
\end{tabular}

Abbreviations: JSH, the Japanese Society of hypertension guidelines for the management of hypertension 2014; BP, blood pressure; SBP, systolic blood pressure; DBP, diastolic blood pressure: CAD, coronary arterialt disease; CDV, cerebrovascular disease; CKD, chronic kidney disease; DM, diabetes mellitus.

control in patients younger than 75 years including patients with CAD and CVD was $69.1 \%$. The rate of BP control in CKD patients with non-diabetic proteinuria who were not late-phase elderly was $11.9 \%$. In all cases, the rate of controlled BP in the office was higher than that in the home.

Comparisons between Patients in whom BP was Controlled or Non-Controlled in Patients 75 Years and Older, and in Patients Younger than 75 Years (Table 3)

Among patients 75 years and older, the total number of antihypertensive agents and the scores used for the treatment of hypertension in patients were significantly higher in the noncontrol group. However, the medication compliance was significantly greater in the BP control group than in the non-control group $(91.0 \%$ vs. $76.2 \%)$ in patients 75 years and older, and it was similar in the patients younger than 75 years group. In patients younger than 75 years, the total number of antihypertensive drugs and their scores were not significantly different. The average age and sex ratio were significantly different in that the non-control group was younger than the control group and the ratio of males to females was larger in the non-control group.

Comparisons between Patients in whom BP was Controlled or Non-Controlled in Patients with DM, and Non-Diabetic CKD with Proteinuria (Table 4)

There were different patient ${ }^{\prime}$ characteristics in patients with DM. For example, the average age was older, the female-to-male ratio was larger, and the body mass index (BMI) was smaller in the control group than in the noncontrol group. The other factors were not significantly different. In patients with non-diabetic CKD with proteinuria, the total number of antihypertensive drugs was significantly larger in the control group than in the noncontrol group. In terms of the classes of drugs, the usage of beta-blockers was higher in the control group than in the non-control group.

\section{Discussion}

The JSH 2014 guidelines have been revised and differ from the previous JSH 2009 guidelines. In young and middle-aged, low-risk patients with hypertension, the target level for BP control was less than $130 / 85 \mathrm{mmHg}$ in the JSH 2009 guidelines. Thus, there was a gap between the criteria for the initiation of antihypertensive agent therapy and the target level of BP control. Since some research $^{13}$ has demonstrated a significantly decreased number of cardiovascular events in young and middle-aged hypertensive patients when the goal BP levels were lower than $140 / 90 \mathrm{mmHg}$, the target level of BP control was established as less than $140 / 90 \mathrm{mmHg}$ in the JSH 2014 guidelines $^{14}$.

The target level of BP control in patients with DM and non-diabetic proteinuria in CKD is less than 130/80 $\mathrm{mmHg}$, because these patients are at high risk of $\mathrm{CVD}^{15-17}$. The Kidney Early Evaluation Program Observational Study ${ }^{18}$ reported that the incidence of end-stage renal disease was lowest in patients with a systolic BP of 130 to $140 \mathrm{mmHg}$. Thus, the target level of $\mathrm{BP}$ control in non-diabetic CKD patients without proteinuria is less than $140 / 90 \mathrm{mmHg}$.

The target level of BP control in patients with stroke or CAD is less than $140 / 90 \mathrm{mmHg}$. Although evidence regarding the target level of BP in hypertensive patients with CAD is insufficient, the JSH 2014 guidelines recommend it based on the results of the ACTION and JMIC-B trials $^{19-21}$. The target level for patients with stroke remains the same as that in the JSH 2009 guidelines.

Organ damage is frequently observed in late-phase elderly patients, who are older than 75 years. The recom- 
Table 3 Comparisons between target BP achieved and non-achieved groups in patients 75 years or older, and patients younger than 75 years.

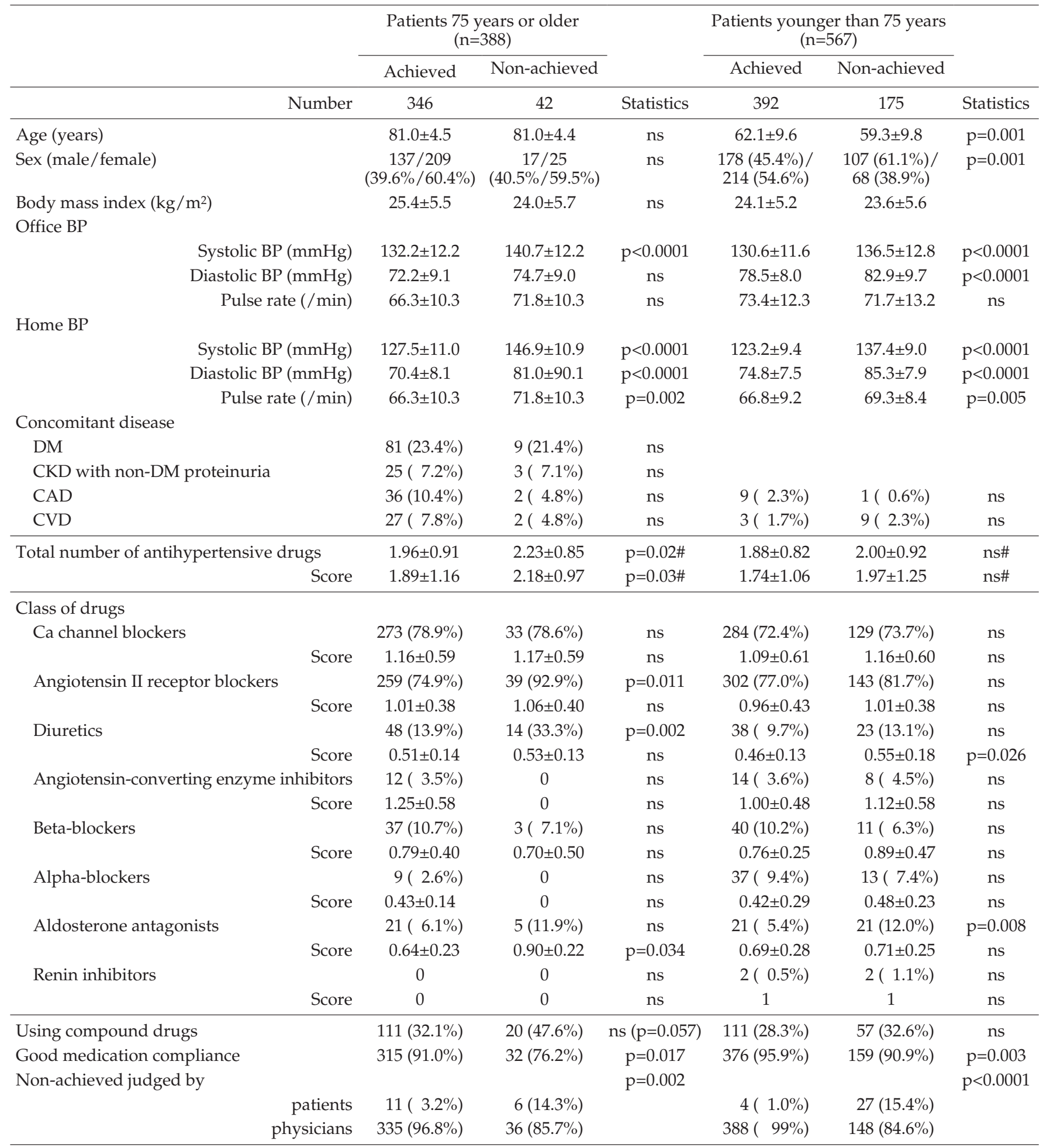

Abbreviations: BP, blood pressure; DM, diabetes mellitus; CKD, chronic kidney disease; CAD, coronary arterial disease; CVD, cerebrovascular disease. The score of antihypertensive drugs was adjusted to the standard dose. \#: The comparison between the groups was calculated by a non-parametric method using the Mann-Whitney test.

mended target level of BP control in these patients is less than $150 / 90 \mathrm{mmHg}$, and if possible, a further reduction to the final target level of less than $140 / 90 \mathrm{mmHg}$. If the age-based target BP differs because of the presence of concomitant disease, the age-based target BP should be set as the first goal. Of course, if these late-phase elderly 
Table 4 Comparisons between target BP achieved and non-achieved groups in DM patients, and CKD with proteinuria but not DM.

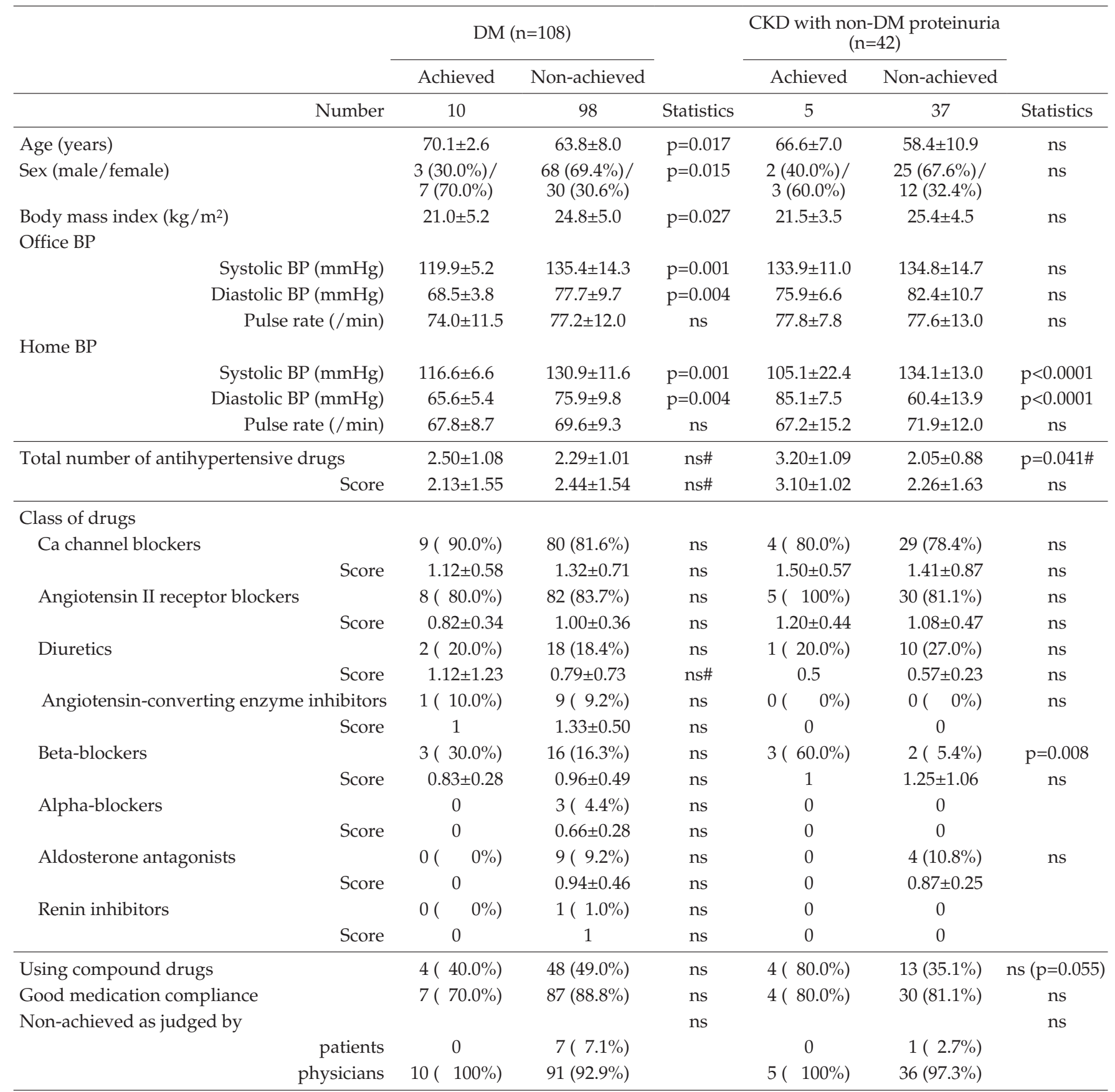

Abbreviations: BP, blood pressure; DM, diabetes mellitus; CKD, chronic kidney disease. The score of antihypertensive drugs was adjusted to the standard dose. \#: The comparison between the groups was calculated by a non-parametric method using the Mann-Whitney test.

patients can tolerate it, a lower target $\mathrm{BP}$ should be aimed for.

The major difference between the JSH 2014 and 2009 guidelines is that, when there is a discrepancy in diagnosis between office BP and home BP, the home BP-based diagnosis has priority. The target levels of home systolic and diastolic BPs are established as $5-\mathrm{mmHg}$ lower than office systolic and diastolic BPs.
Hypertension is the most common lifestyle-related disease. It is primarily managed by clinicians and general practitioners. The JSH 2014 guidelines were prepared for these physicians. It is important to perform a crosssectional survey to investigate actual clinical practice concerning BP control in patients with hypertension following the revision of the guidelines.

According to the JSH 2014 guidelines, the overall 
achievement ratio was $68.1 \%$ (753 out of 1,105$)$ in the present study. Although it was based on different management guidelines, this exceeded the ratio of $53.9 \%$ in $2008,55.1 \%$ in 2009, and $57.1 \%$ in 2011 for surveys in Kanagawa ${ }^{11,12}$.

The highest rate of achievement in target BP level $(89.2 \%)$ (Table 2 ) was seen in the group of late-phase elderly patients. One factor in this achievement of target BP control was good medication compliance $(91.0 \%$ vs. $76.2 \%$ ) (Table 3). The achievement ratio in patients younger than 75 years (excluding patients with DM and non-diabetic proteinuria, but including patients with CAD and CVD) was $69.1 \%$. Patients' characteristics such as a relatively older age (62.1 \pm 9.6 vs. $59.3 \pm 9.8$ years $)$ and a larger population of females (54.6\% vs. $38.9 \%$ ) may contribute to good BP control in these patients (Table 3).

In patients with $\mathrm{DM}$, the achievement ratio of the target BP control was very poor, such as only 9.3\%. However, the factors that contributed to BP control included a relatively older age (70.1 \pm 2.6 vs. $63.8 \pm 8.0$ years), a larger population of females $(70.0 \%$ vs. $30.6 \%)$, and a smaller BMI $\left(21.0 \pm 5.2\right.$ vs. $\left.24.8 \pm 5.0 \mathrm{~kg} / \mathrm{m}^{2}\right)$ (Table 4). However, in non-diabetic CKD patients with proteinuria, the achievement ratio of BP control was also very poor, such as $11.9 \%$. In these patients one factor of success in $\mathrm{BP}$ control was more aggressive antihypertensive treatment. The total number of antihypertensive agents was $3.2 \pm 1.09$ in the control group and $2.05 \pm 0.88$ in the noncontrol group (Table 4). Patient' characteristics were not significantly different between groups; however, the number of patients in these groups was limited. In these two poor BP control groups, more than $90 \%$ of physicians judged these BP levels as permissible (Table 4). The Fukushima research of hypertension ${ }^{22}$ study pointed out that the necessity of improvement in physicians' awareness concerning the management of hypertension according to treatment guidelines and the importance of a healthy lifestyle to maintain goal BP levels. These poor achievement ratios may be due to the strict target levels of BP control, especially in home BP levels, such as less than $125 / 75 \mathrm{mmHg}$. There were no significant differences in office BPs between the two groups but significant differences were seen in home BPs. This may be due to the poorly known new concept that, when there is a discrepancy in diagnosis between office BP and home BP, the home BP-based diagnosis should have priority.

Our study had some limitations. First, this was a crosssectional analysis. Second, this study was performed only six months after the new JSH guidelines were estab- lished. Third, CAD and CVD patients were included in the patients younger than 75 years group since the numbers of those patients were very small (CAD in 10 cases and CVD in 12 cases) and they had the same BP criteria. Further follow-up survey data are necessary for a full assessment.

Acknowledgements: We wish to thank all physicians of the Kanagawa Physicians Association who participated in this study.

Conflict of Interest: The authors declare no conflict of interest.

\section{References}

1. Antikainen R, Jousilahti P, Tuomilehto J: Systolic blood pressure, isolated systolic hypertension and risk of coronary heart disease, strokes, cardiovascular disease and all-cause mortality in the middle-aged population. $\mathrm{J} \mathrm{Hy-}$ pertens 1998; 16: 577-583.

2. Lida M, Ueda K, Okayama A, Kodama K, Sawai K, Shibata S, Tanaka S, Keijnkai T, Horibe H, Minowa M, Yanagawa H, Hashimoto T; Nippon Data 80 Research Group: Impact of elevated blood pressure on mortality from all causes, cardiovascular diseases, heart disease and stroke among Japanese: 14 year follow-up of randomly selected population from Japanese-Nippon data 80. J Hum Hypertens 2003; 17: 851-857.

3. Arauz-Pacheco C, Parrott MA, Raskin P: The treatment of hypertension in adult patients with diabetes. Diabetes Care 2002; 25: 134-147.

4. Geiss LS, Rolka DB, Engelgau MM: Elevated blood pressure among U.S. adults with diabetes, 1988-1994. Am J Prev Med 2002; 22: 42-48.

5. Chobanian AV, Bakris GL, Black HR, Cushman WC, Green LA, Izzo JL Jr, Jones DW, Materson BJ, Oparil S, Wright JT Jr, Roccella EJ; National Heart, Lung, and Blood Institute Joint National Committee on Prevention, Detection, Evaluation, and Treatment of High Blood Pressure; National High Blood Pressure Education Program Coordinating Committee: The Seventh Report of the Joint National Committee on Prevention, Detection, Evaluation, and Treatment of High Blood Pressure: the JNC 7 report. JAMA 2003; 289: 2560-2572.

6. Mancia G, De Backer G, Dominiczak A, Cifkova R, Fagard R, Germano G, Grassi G, Heagerty AM, Kjeldsen SE, Laurent S, Narkiewicz K, Ruilope L, Rynkiewicz A, Schmieder RE, Boudier HA, Zanchetti A; ESH-ESC Task Force on the Management of Arterial Hypertension: 2007 ESH-ESC Practice Guidelines for the Management of Arterial Hypertension: ESH-ESC Task Force on the Management of Arterial Hypertension. J Hypertens 2007; 25: 1751-1762.

7. Whitworth JA; World Health Organization, International Society of Hypertension Writing Group: 2003 World Health Organization (WHO)/International Society of Hypertension (ISH) statement on management of hypertension. J Hypertens 2003; 21: 1983-1992.

8. Guidelines for the management of hypertension for general practitioners. Hypertens Res 2001; 24: 613-634.

9. Japanese Society of Hypertension guidelines for the man- 
agement of hypertension (JSH 2004). Hypertens Res 2006; 29 (Suppl): S1-105.

10. Ogihara T, Kikuchi K, Matsuoka H, Fujita T, Higaki J, Horiuchi M, Imai $Y$, Imaizumi T, Ito S, Iwao H, Kario K, Kawano Y, Kim-Mitsuyama S, Kimura G, Matsubara H, Matsuura H, Naruse M, Saito I, Shimada K, Shimamoto K, Suzuki H, Takishita S, Tanahashi N, Tsuchihashi T, Uchiyama M, Ueda S, Ueshima H, Umemura S, Ishimitsu $\mathrm{T}$, Rakugi H; Japanese Society of Hypertension Committee: The Japanese Society of Hypertension Guidelines for the Management of Hypertension (JSH 2009). Hypertens Res 2009; 32: 3-107.

11. Hatori N, Sakai H, Sato K, Mitani K, Miyajima M, Yuasa S, Kuboshima S, Kajiwara K, Miyakawa M: Changes in blood-pressure control among patients with hypertension from 2008 through 2011: surveys of actual clinical practice. J Nippon Med Sch 2014; 81: 258-263.

12. Hatori N, Sato K, Miyakawa M, Mitani K, Miyajima M, Yuasa S, Furuki T, Matsuba I, Naka K: The current status of blood pressure control among patients with hypertension: a survey of actual clinical practice. J Nippon Med Sch 2012; 79: 69-78.

13. Zanchetti A, Grassi G, Mancia G: When should antihypertensive drug treatment be initiated and to what levels should systolic blood pressure be lowered? A critical reappraisal. J Hypertens 2009; 27: 923-934.

14. Shimamoto K, Ando K, Fujita T, Hasebe N, Higaki J, Horiuchi M, Imai Y, Imaizumi T, Ishimitsu T, Ito M, Ito S, Itoh H, Iwao H, Kai H, Kario K, Kashihara N, Kawano Y, Kim-Mitsuyama S, Kimura G, Kohara K, Komuro I, Kumagai H, Matsuura H, Miura K, Morishita R, Naruse M, Node K, Ohya Y, Rakugi H, Saito I, Saitoh S, Shimada K, Shimosawa T, Suzuki H, Tamura K, Tanahashi N, Tsuchihashi T, Uchiyama M, Ueda S, Umemura S; Japanese Society of Hypertension Committee for Guidelines for the Management of Hypertension: The Japanese Society of Hypertension Guidelines for the Management of Hypertension (JSH 2014). Hypertens Res 2014; 37: 253390.

15. Kawamori R, Fujita T, Matsuoka H, Umemura S, Saito Y: Relation between cardiovascular complications and blood pressure/blood glucose control in diabetic patients with hypertension receiving long-term candesartan cilexetil therapy: Challenge-DM study. Diabetes Res Clin Pract 2009; 83: 241-248.

16. Nakayama M, Metoki H, Terawaki H, Ohkubo T, Kikuya
M, Sato T, Nakayama K, Asayama K, Inoue R, Hashimoto J, Totsune K, Hoshi H, Ito S, Imai Y: Kidney dysfunction as a risk factor for first symptomatic stroke events in a general Japanese population - the Ohasama study. Nephrol Dial Transplant 2007; 22: 1910-1915.

17. Ninomiya T, Kiyohara $Y$, Kubo M, Tanizaki $Y$, Doi $Y$, Okubo K, Wakugawa Y, Hata J, Oishi Y, Shikata K, Yonemoto K, Hirakata H, Iida M: Chronic kidney disease and cardiovascular disease in a general Japanese population: the Hisayama Study. Kidney Int 2005; 68: 228-236.

18. Peralta CA, Norris KC, Li S, Chang TI, Tamura MK, Jolly SE, Bakris G, McCullough PA, Shlipak M; KEEP Investigators: Blood pressure components and end-stage renal disease in persons with chronic kidney disease: the Kidney Early Evaluation Program (KEEP). Arch Intern Med 2012; 172: 41-47.

19. Bangalore S, Kumar S, Volodarskiy A, Messerli FH: Blood pressure targets in patients with coronary artery disease: observations from traditional and Bayesian random effects meta-analysis of randomised trials. Heart 2013; 99: 601-613.

20. Lubsen J, Wagener G, Kirwan BA, de Brouwer S, PooleWilson PA: Effect of long-acting nifedipine on mortality and cardiovascular morbidity in patients with symptomatic stable angina and hypertension: the ACTION trial. J Hypertens 2005; 23: 641-648.

21. Yui $Y$, Sumiyoshi T, Kodama K, Hirayama A, Nonogi H, Kanmatsuse K, Origasa H, Iimura O, Ishii M, Saruta T, Arakawa K, Hosoda S, Kawai C; Japan Multicenter Investigation for Cardiovascular Diseases-B Study Group: Comparison of nifedipine retard with angiotensin converting enzyme inhibitors in Japanese hypertensive patients with coronary artery disease: the Japan Multicenter Investigation for Cardiovascular Diseases-B (JMIC-B) randomized trial. Hypertens Res 2004; 27: 181-191.

22. Yokokawa H, Goto A, Sanada H, Watanabe T, Felder RA, Jose PA, Yasumura S: Achievement status toward goal blood pressure levels and healthy lifestyles among Japanese hypertensive patients; Cross-sectional survey results from Fukushima research of hypertension (FRESH). Intern Med 2011; 50: 1149-1156.

(Received, January 16, 2016)

(Accepted, April 21, 2016) 